\title{
Economy as Matching
}

Philippe Steiner

\section{Abstract}

Recently, a new definition of the economy appeared in which matching is central stage. Matching means that there exist some specific issues related to the effective association of a given resource with a given person. Matching may thus appear an extension of the traditional issue related to the distribution of wealth; against this appearance, the present communication emphasizes that something else is at stake when it comes to understanding how matching is actually implemented.

The first part of the communication is devoted to explaining what is meant by matching in the present state of the economy, with a special emphasis on the works of Alvin Roth. The second part is about the sociological underpinnings of the matching approach to economic issues, showing how different it is from the market. Finally, the third part connects economy as matching to Michel Foucault's understanding of pastorate, focusing on the changes brought about by the huge amount of data and the technology necessary to implement a new form of governmentality, that in which, according to the old religious precept, the leader must govern the population as a whole and each individual in particular ("omnes et singulatim" in Foucault's terms).

Keywords: matching, algorithm; economic sociology

\section{Introduction}

Since the second half of the $18^{\text {th }}$ century a plurality of definition of the subject matter of political economy, and then economics, have been designed by leading economists. These definitions range from material ones, when the science is about wealth, understood as the set of resources that are both useful and difficult to produce (from Anne-Robert-Jacques Turgot to Jean-Baptiste Say, David Ricardo and John Stuart Mill), to formal ones, when it is all about the rational use of scarce and useful goods that may be useful in different settings (from Lionel Robbins to Paul Samuelson).

I Sorbonne Université.

$(\mathrm{cos}) \mathrm{EY}$
Direito autoral e licença de uso: Este artigo está licenciado sob uma Licença Creative Commons. Com essa licença você pode compartilhar, adaptar, para qualquer fim, desde que atribua a autoria da obra, forneça um link para a licença, e indicar se foram feitas alterações. 
Beyond that diversity, there exist some commonalities stemming from the fact that economists are, most often, endeavoring to set the laws regulating the production, distribution and exchange - sometimes the consumption - of wealth or of these scarce and useful goods susceptible of alternative uses. This common threat applies in the case of the micro approach to political economy, from Adam Smith's famous chapter 7 on the functioning of a market in the Wealth of the Nations, to Gary Becker's and Jean Tirole's extended economic approach to human behavior; it applies as well at the macro level, from François Quesnay's Economic Table to Thomas Piketty's Le capital au $21^{e}$ siècle.

Recently, a new definition of the economy appeared in which matching is central stage. Matching means that there exist some specific issues related to the effective association of a given resource with a given person. Matching may thus appear an extension of the traditional issue related to the distribution of wealth; against this appearance, the present communication emphasizes that something else is at stake when it comes to understanding how matching is actually implemented.

The first part of the communication is devoted to explaining what is meant by matching in the present state of the economy, with a special emphasis on the works of Alvin Roth, an economist who received in 2012 the Prize of the Bank of Sweden in honor of Alfred Nobel for his work on matching markets. The second part is about the sociological underpinnings of the matching approach to economic issues, showing how different it is from the market. Finally, the third part connects economy as matching to Michel Foucault's understanding of pastorate, focusing on the changes brought about by the huge amount of data and the technology necessary to implement a new form of governmentality, the one in which the old religious precept requiring the leader to govern the population as a whole and each individual in particular ("omnes et singulatim" in Foucault's terms) becomes effective.

\section{Economics as matching}

Matching is a further development of political economy since it is fundamentally dealing with the issue of the distribution side that pertains 
to that science since the beginning - the most famous piece of political economy written by Turgot was published in 1766 as Reflections on the formation and the distribution of Wealth(TURGOT, [1766], 1914). More precisely, we may connect the issue of matching with markets, the central institution of modern economy, as it is clear with Smith's chapter on the market, even if this is generally blurred by the importance given to the gravitation of market prices around natural ones. However, if one looks at the process thanks to which this gravitation occurs, then the matching issue appears strongly connected to competitive relations on the market:

A competition will immediately begin among them buyers confronted to a shortage of goods, and the market price will rise more or less above the natural price, according to either the greatness of the deficiency, or the wealth and wanton luxury of the competitors, happen to animate more or less eagerness of the competition. (SMITH, [1776] 198I, I, p. 73-74).

\section{I Matching: market and arena ${ }^{2}$}

The competitive allocation process driven by the setting of an equilibrium price is a satisfying proxy for the matching issue as long as some structural conditions in the functioning of the market are left out ${ }^{3}$. Beyond this general connection, matching involves something more than the formation of a price (or a shadow price) that clears the market or even more than the formation of pairs maximizing output (BECKER, [1973] 1978). Structural elements involve issues about preferences, quality, and information (STOVEL; FOUNTAIN, 2009; COLEMAN, 1984).

Matching is about the precise allocation of a resource - be it a person, a service or a material good - to a specific person under the constraint of

2 Throughout this communication, I use arena in the sense suggested by Harrison White (1992, p. 30-32). On an arena, "actors are there to make matching" (WHITE, 1992, p. 52) in a one shot process designed to "select" and "purify".

3 See for example, Alfred Marshall's chapter "On Market" when he explained that general markets require a universal demand and things that can be easily and exactly described: "Thus for instance cotton, wheat, and iron satisfy wants that are urgent and nearly universal. They can be easily described, so that they can be bought and sold by persons at a distance from one another and at a distance also from the commodities. If necessary, samples can be taken of them which are truly representative; and they can even be 'graded' as is the actual practice with regard to grain in America, buy independent authority" (MARSHALL, [1920] I96I, I, p. 326). Léon Walras' general equilibrium of "well organized markets" is grounded on the same assumption: goods, wheat and barley, are nothing but abstract "essence in the philosophical meaning of the term" (WALRAS, [1900] 1988, p. 44). 
symmetrical preferences according to which a match occurs if and only if $a$ prefers $b$ to any other possible match and $b$ prefers $a$ to any other possible match. On matching arena it is not enough to have preferences over resources since "resources" have as well preferences on them. On markets the good bought and sold is standardized, as economists implicitly assumed. However, once the resource is not homogeneous, the issue of allocation becomes more complicated: it is not enough to get a piece of the resource you need (a student room on the campus, a kidney for transplantation, a position in an hospital, or in a school etc.), because people have as well preferences on some other dimension of the resource (a room close to one's friends, a kidney with a better fit with one's body, an hospital in a given city, a school that stands higher in local reputation ranking). In all these cases, resources are not homogeneous from the point of view of the "demand" side. This applies in many cases to the "supply" side: for those in charge of managing the accommodation of students, the transplant system, the functioning of an hospital or of a school, all the applicants are not exactly similar. Accordingly, the exact matching between a piece of the resource and a person raises specific problems beyond the classic issue of asymmetric information or beyond Lucien Karpik's definition of "singularities", that is to say cultural goods defined both by their quality and a deep uncertainty about what constitutes the good quality (KARPIK, 2010). Matching is a more general and demanding process since it involves goods that are not cultural in the proper sense of culture -the evaluation of a kidney has nothing to do with culture, but with biology - and requires the solution of double problem of quality assessment for a pairing that has important and longstanding consequences. Finally, matching requires that actors on both side of the matching arena have information on the actors they face in order to perform the three tasks of screening, selecting and then matching. The required flows of information can create several difficulties or "transaction costs": getting information is costly, the matching process can be plagued by search costs but, conversely, information can be overabundant and thus difficult to manage. For this reason, there exist matchmakers whose job is to cut transaction costs for the actors; but this is as well why matching arenas adopt a centralized structure (similar to a Walrasian market) instead of a decentralized one (similar to an Edgeworthian market), as showed in schema I. 
Empirically, sociologists have studied matching processes since a long time in order to see whether a specific type of match is characterized by homophily or heterophily (i.e. the tendency to match with similar or different people). This is notably the case when one is interested in the sociology of family and marriage; this is also the case with network analysis (STOVEL; FOUNTAIN, 2009); sociologists consider this issue as well in more surprising and limited settings such as pair formation in aikido tournaments (DUPREZ; BARBUT,2007). Matching is as well an old approach when it comes to labor market, for example in order to find how people get their job (GRANOVETTER, 1974), or why job contracts are broken (MORTENSEN, 1988). All these cases are about non-centralized Edgeworthian arenas. More recently, due to the huge transformation brought about by information technology, matching became a key issue for economists with the growth of platforms or multisided markets where an entrepreneur builds a meeting place on Internet where the two sides of a market will gather and then interact, producing matches and thereby creating a value that the entrepreneur expects to grasp. The economic theory of such markets - notably the interrelation between the two "demands", and the unusual pricing model according to which one demand side may be paid to appear on the market - was elaborated by Jean Tirole - see for example Tirole (2016, chap. 14) whereas the basics of the management of the transaction costs reducing Internet platforms thanks to which such markets are operating is now a thriving field of publication for those who have expertise in this new domain (EVANS; SCHMALENSEE,2016; PARKER; VAN ALSTYNE; CHOUDARY, 2016).

\section{Schema I}

Relational configuration of centralized and decentralized arenas
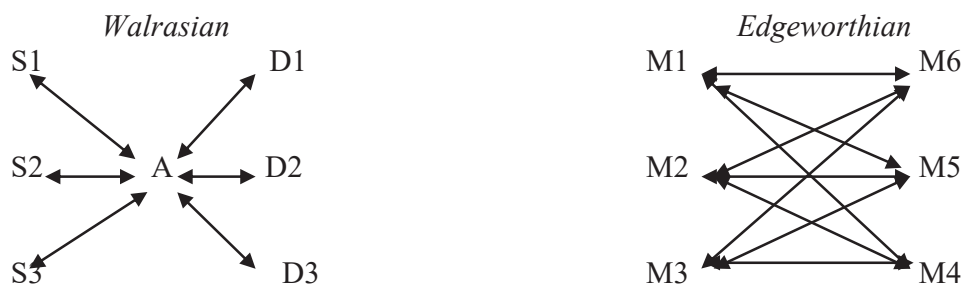
In a Walrasian arena, participants are only connected to an auctioneer who is the central actor for the information graph, with a maximal degree of centrality. In this market organization, the central entity does not collect resources that have been produced or demanded, but limits itself to centralizing information so that equilibrium prices can be achieved; then exchange of resources takes place in the economy according to the distribution of preferences among market actors. In an Edgeworthian arena, each entity is directly connected with all the others in order to negotiate and re-negotiate the conditions of exchange so that, in the end, the arena converges toward an equilibrium price, theoretically equal to the Walrasian equilibrium price if the number of entities involved is high enough. In the Walrasian approach the issue is to find the true price for reaching the equilibrium that is as well an optimum; in the Edgeworthian process, the issue is to find the path leading to this equilibrium.

Economic theoreticians and business scholars agree for stressing the key role played by the management of information. In Tirole's case, this is straightforward since his theoretical expertise lays in the economy of information, which appeared in the 1970s and 1980s when the Walrasian General Equilibrium research program was abandoned. For him, this platform economy is about the management of the information required to perform a search (a job, a partner, a seller etc.) leading to an exchange when there is too much information and thus a high research cost: platforms are providing what, as soon as 1969, Herbert Simon has called the "economy of attention". There are as well specific information issues related to this platform economy, notably the one related to the ownership of data and information and the one attached to trust: the customer must trust the information sent by the other side of the platform and she must as well trust the algorithm that selects the possible matches that may correspond to the customer's demand and behavior. Management of information is important for business scholars. Platforms require that actors send information or, even, fill out a questionnaire, and then an algorithm selects in the data basis that corresponds to what is looked for by actors; other platforms use data collected on the web in order to find commonalities between actors who are then connected to each other, expecting them to match, that is to say to exchange and thus create a value that platforms 
grasp partially. These software or "filters" (PARKER; VAN ALSTYNE; CHOUDARY, 2016, p. 40) are producing possible matches - no one is obliged to buy the books that Amazon's algorithm suggests when one buys a book on this website. They are reducing the search cost, they are as well forms of advertisement aiming at bringing the recipient to buy something, but they are not directly making matches.

There exist thus a large number of software at work on platforms designed to transforming the working of the economy through the multiplication of Internet market places. However, most of them are not about matching: "These platforms are selling connections" as David Evans and Richard Schmalensee aptly say (2016, p. 35). Their software simplifies the problem of finding relevant information and channels their customers to possible matches; but they are not properly matching platforms. In order to be more specific, I would like to focus on a more limited set of Walrasian platforms in which matching is the direct goal and outcome, and not simply a possible one. These two restrictions are significant, of course, since there are matching arenas - notably the job market — where such a centralization does not exist and since there exist centralized arenas that do not provide matches but interaction; however, the number of these Walrasian matching platforms is large enough to include market and non-market transactions, the latter being generally omitted from the economic literature so far.

\subsection{Algorithmic Walrasian matching arenas}

The modern study of algorithmic matching begun with by David Gale and Lloyd Shapley's seminal paper published in a mathematical journal (GALE; SHAPLEY,1962). In this paper, they proposed a technique deferred acceptance - and an evaluation of its results in terms of optimality. In their paper they explained that a two-sided arena in which individuals have preferences (a ranking) over the individuals on the other side has a stable solution in the sense that there exist no blocking pair, that is to say two individuals, $a$ and $b$, respectively matched with other people whereas both $a$ and $b$ would prefer to be matched together. Furthermore, the solution is optimal in the sense that no individual can get a better position in any other stable solution. They demonstrated as well that there existed different equilibria according to the side getting the priority. The principle of deferred acceptance is the following. Let's suppose a set of men and a 
set of women, in equal number, in which every individual ranks all the individual of the opposite set; let's suppose that priority is given to women (they propose first): at the first step, all the men who receive one or several proposals, rejects all of them but the highest in his ranking. Nevertheless, this is not his final choice, since if all the women have send a proposal to the man who is on top of her ranking, and if the men have selected the women who is the highest on his ranking, that does not mean that the women selected at this first step is the highest in his ranking (she is only the highest among the proposals received so far). Acceptance is thus only conditional. At the second steps, the woman whose proposal have been rejected send a proposal to the men who is second in their ranking, the men who received one or several proposals select the highest of these proposal and the one they may have accepted at the previous step. After a finite number of steps, each man has received a proposal, and has selected the highest proposal received all along the series of steps. This matching is stable: if Laura prefers Peter to his match Paul, she has sent a proposal to Peter, who rejected it because he prefers his match to Laura. There is no blocking pair and thus no "justified envy".

Then, other techniques and algorithms were elaborated, notably the “Top Trading Cycle" by Lloyd Shapley and Herbert Scarf, the algorithm being provided by Gale. This often related to the housing allocation between students. Let suppose that each student of a university has got a room; nevertheless, some students would prefer a different house than the one resulting from the initial allocation. The algorithmic solution to this allocation issue starts from requiring that students rank the rooms, indicating what is the room preferred by each of them (the "Top"). Then, the algorithm looks for cycles in order to match students with the room which is preferred: if $a$ prefers room 1 to his room 2 , whereas $b$ prefers room 2 to his room 1, there is a cycle of length 2 . Both students exchange their room and are in a better situation both of them. Then these two students and their rooms are removed and the algorithm looks for a new cycle - note that a cycle could be of length 1 , when a student prefers the room coming from the initial allocation. When there is no more cycle, there are no more mutually beneficial exchanges and the matching process is ended. This matching technique has some interesting properties, notably the solution is unique and the process is strategy-proof in the sense that 
it is never advantageous for an agent to cheat about her preference. It is important to notice that these path-breaking results are about centralized Walrasian arenas; the study of decentralized Edgeworthian arena is much less developed, eve, if it was shown that the random path at work on these arenas is similar to the Gale and Shapley's deferred acceptance (ROTH; VANDE VATE, 1990).

This approach was taken up by Alvin Roth, an economist in Harvard, now in Stanford after receiving the Noble prize in 2012, who explored the mathematics of matching on the one hand, and developed a new approach of political economy as "economic engineering" (ROTH, 2002, ROTH; PERANSON, 1999) on the other. This has two consequences.

First, this approach to economic theory is still in line with the "classical" definition of political economy in the sense that the distribution (or allocation) of resources is one important element of political economy since the middle of the $18^{\text {th }}$ century. However, it is important to stress that the "economics as matching" approach modifies significantly the institutional underpinnings of economics. Usually, economics is strongly associated to market, an institution characterized by the fact that there is two sets of people exchanging resources after they agree on a price for the goods and a mechanism to get the goods, notably competition. In that case, either the first to ask for the good at the agreed price, or the one who offers the highest price for the good, get it; in any case, the buyer must have the financial resource necessary to play the market game. It has already been explained that matching structures are quite different from what is generally assumed by economists' views on markets ${ }^{4}$. However, this remark must be pushed further: matching is a general social phenomenon that have no reason to be not limited to markets since matching can happen on different arenas of exchange for allocating goods that are not scarce.

4 "Another example of markets in which social structure is important is the matching process that occurs in monogamous marriage or in job markets. Sociologists and demographers call this assortative mating. It is clearly a social process with some complexity. It can, however, be seen as an economic exchange market in which each actors has exactly one good to trade, and can get exactly one in return. Yet it is very different from a neo-classical perfect market. For example, the role of 'price' as allocation mechanism is greatly altered; and the entities exchanged are not fungible - there is not a market in trading wives" (COLEMAN, 1984, p. 86). In his Foundations of Social Theory, Coleman comes back to this topic in order to link the micro and the macro dimensions of the marriage issue thanks to the deferred acceptance algorithm (COLEMAN,1990, p. 22-23). 
In the matching world, there are significant modifications to the institutional underpinnings even when the matching process resembles a labor market as it is the case with the medical resident matching program. This comes from the fact that there is no price in such "matching markets". Students are not mainly driven by the money they would get from the hospital they rank first, since more is involved in the choice of a hospital: geographical location, career prospect, research etc. Conversely, the hospitals are not competing in terms of the wage offered to the medical residents. This economics is not grounded on price and financial resource, but on "fit", or more precisely on "being selected", that is on choice driven by preferences. One may say that this does not make a big change since preferences are the grounding stone of economics since the end of the $19^{\text {th }}$ century, and are the rationale for the behavior of market actors. This reaction is misleading since if it is true that preferences and choice are important elements of market activity and theory, they are not limited to the institution of the market: choice and preferences are the basic fuel of many other social arena than the market, precisely in many social arena where matching is at stake, as this is the case with the social arena of organ transplantation and the international ban of market exchange of kidney ${ }^{5}$. So, if it is true that markets imply choice and preferences, the reverse is not true: choice and preferences do not imply the market. There exist several possibilities to make clear the consequences of this non sequitur statement. First, as mentioned above, there exist matching arenas (school choice, organ transplantation etc.) on which price and money are pointless; second, on these arenas the central issue is on distributive justice - i.e. the equal opportunity of access - and not the commutative justice which economists have put at the core of the institution of the market ${ }^{6}$. Matching economics is about allocation of resources, but these allocations are processed on social arenas of which markets are only a sub-set. It is necessary to bear in mind the generality of the matching process when it comes to analyzing the social basis of matching economics.

5 The only exception is the regulated market for kidney in the Islamic republic of Iran, since a law enacted in 1987.

6 Walras was clear on this issue: appropriation is a "humanitarian fact" involving the issue of distributive justice whereas market exchanges are "natural facts" confronted to commutative justice (WALRAS, [1900] 1988, 4th Lesson, p. 57-66). See as well Friedrich Hayek on the issue of catallactic justice in a spontaneous order (HAYEK, 1976, chap. 9 and 10). 
Second, this algorithmic approach to the distribution of goods has given birth to what Roth has called "economic engineering". This means that economists are no longer using the same kind of mathematical tools, they leave out the search for general results and theorems, for focusing on the pragmatic working of a given arrangement or device. The use of simulation becomes then very important, in order to test various possibility when designing the matching software (ROTH, 2002; ROTH; PERANSON, 1999). This means that these economists are no longer limited to describing or analyzing the economic world out there, but are constructing the arenas in which algorithmic allocation can be implemented (Seiner 2010, and 2016, chap. 6-7). We are thus at the precise point for bringing together the different theoretical underpinnings of the present research, since, as an economic engineer, Roth has built arenas mimicking the basic principles of the (labor) market mechanism with the resident - hospital program (ROTH, 2003, ROTH; PERANSON, 1999) and other who differ significantly from these principles, as it is the case with organ transplant for non-compatibles pairs of donor and recipient (ROTH; SÖNMEZ; ÜNVER, 2004, 2005; ROTH; SAIDMAN, 2006), since the basic requirement for entering this arena is not money and capacity to pay in a competitive environment, but to get a friend or a sibling ready to donate a kidney. Accordingly, the nature of the resource one the one hand, and the nature of the social underpinnings (particularly the set of people and the way they enter into the matching system) are to be considered with some scrutiny in order to go beyond the mathematics of the "economics as matching".

\section{The social basis of the matching economy}

As mentioned above, sociologists have emphasized how matching structures differ from market ones when it comes to actor's preferences, good's quality and information flows. Nevertheless other structural elements must be taken into account. As soon as one considers "economics as matching" as a structured social process, three elements are of key importance: a specific institution located at the center of the process, that Roth a suggested to label a "Clearinghouse"; specific groups that are strongly connected to the institution, that I propose to call "Blocks"; and, finally, a relational process of sending specific information to the software located at the core of the institution. After a general description of this 
social structure, I will study how the French Agence de la biomédecine matches patients on the waiting list for a kidney graft and kidneys coming from post mortem procurements.

\section{I Blocks, Clearinghouse and matching software}

As mentioned above, the elegant results demonstrated by Gale and Shapley are based on the existence of two populations that have preferences over the member of the opposite population. So far, economists have considered that the key issue was to design a matching device that would require to sending the true preferences to the Clearinghouse; accordingly, it would be useless to look for false preferences that would maximize the chance to reach one's best choice.

But what does it means to the population that have to go through the matching device? How do these populations face these matching devices and, finally, what can we say about these populations? These are the central question to be answered from a socio-economic point of view.

The first point to clarify is the fact that these populations are examples of a new form of social entity, that I propose to call "Block", because their existence can be studied by what is known as "Blockmodelling" in social network analysis (FAUST; WASSERMAN, 1995, chap. 10). Blockmodelling comes from the definition of structural equivalence, according to which two individuals are equivalent if they send and receive links from and to the same actors in the network (LORRAIN; WHITE,1971, p. 63). Accordingly, individuals acting on both sides of an arena are in a situation of structural equivalence since they send and receive links from and to the Clearinghouse, and thus to the opposite blocks, composed of individual with whom they will be matched (schema II). This two sides or "Blocks" are thus made of individuals that share a common identity on the arena, either as a "patient" or as a "donor", even if this does not mean that individuals composing the Blocks are directly connected to each other - usually they don't. 


\section{Schema II}

Blocks and Clearinghouse on an Arena

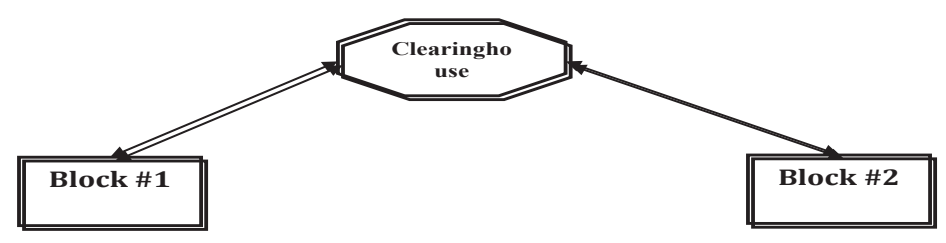

Once this basic and simple structure is brought to light, many questions arise. First, distinction must be made among the way people are selected when entering into one of these Block. In some instance, the selection process is quite limited in the sense that block's membership is compulsory: French children must go to school and thus are required to fill out the documents necessary to find an assignment thanks to AfFeLnET or APB, two Internet platforms that match them with high schools and universities. In many other cases, membership is optional, and generally associated to a selection process that may either straightforwardly exclude some people if they do not meet the required quality for entering the matching arena or sort them out in different categories according to their relevant performance or status. This is generally the case for transplant activity, since local hospitals and surgeons decide whether or not they will put a patient on the waiting list and under which category ("urgency", "super urgency", "hyper immunized", "rare HLA group" etc.). In other instances, such as school, the section process is less dramatic and more open to public scrutiny since almost all the children will go to high school, and many of them will go to a college or a university. But in many other cases, membership is not so complicated and arrives simply once in a life because actors are growing older and have succeeded passing some examination. This is notably the case for pupils and students facing educational institutions; this as well the case for medical students with hospitals. In all of these cases, an individual is not supposed to come back in the block: the matching process is just a one shot process. In some other cases, the possibility of an actor coming back for benefitting from a new match is an important issue: this happens with kidney transplantation for young people, because it may be necessary to offer them a second graft if 
the first kidney fails some few years later. In that case, the first match is somewhat more complicated to perform since it is necessary to avoid the consequence of the hyper immunization that results from the first graft, preventing the potential second one.

Second, there exist a deep asymmetry between Blocks, according to the nature of their populations. In many instances, there are individuals (pupils, physicians) on the demand side, whereas organizations (high schools, hospitals) are on the supply side; but it may happen that the supply side is made of material items, as it is the case with transplantation where patients in the first block are waiting for kidney appearing in the second Block. Accordingly, the preferences sent to the Clearinghouse differ: individual preferences formation raise different issues than organizational ones. In the first case, the issue is to understand how to proceed to make individual send their true preference and to avoid to giving too much importance to the social capital at the disposal of the individual, or any other relevant characteristic (age, gender, geographical location etc.); on the other, it is to know who will be in charge to set the organization's preferences, and on which basis. In some other instances, there are individuals on both sides, even if they are not exactly of the same nature.

Third, there is as well the issue of the kind of cohesion that exists among the individuals. They have no reason to know and meet each other; however, they belong to the same Block because they are connected to the opposite Block through the matching device at work on their arena. Obviously, in some instances, individuals entering a Block may have strong social connections (medical residents may have studied in the same university), but there is no reason to suppose the existence of such social links between people entering the waiting list for a kidney graft. Nevertheless, initial absence of links does not prevent a process of link formation once individuals become members of the same Block: working in the same hospital as a medical resident, studying in the same high school or university or going through regular biopsy exams may create strong and long lasting links between actors. Thus, even if Blocks do not suppose previous links between members, they may create them.

Fourth, the time dimension in membership in a given Block may be significantly different according to the nature of the matching arena. 
Block's membership is not supposed to be a permanent situation: pupils and students are supposed to get an assignment in a high school or a university for the next academic year; medical residents are in the same situation for getting a position in an hospital just after passing their final exams. In other cases, Block's membership cans be somewhat durable, too durable! This is particularly the case with organ transplantation where the efficiency of the medical system is often evaluated according to the number of people who are on the waiting list (i.e. Block \#1 of schema II) and the time they wait while on the list (STEINER, 2010b, chap. 1) ${ }^{7}$. The other side of the matching arena can be very different in terms of the time dimension: contrary to individual actors who are not supposed to stay during a long period of time in Block \#1, when Block \#2 is made of institutions (high schools, universities, hospitals etc.), the latter are supposed to perform their task during a long - centuries in the case of Universities - period of time. They are committed to offer positions to the people who face them in the matching arena. However, the time dimension could be much shorter on Block \#2, as it the case with kidney transplantation. In that specific instance, Block \#2 is made of kidneys that are harvested on a flux of brain dead patients for whom there is an agreement, either from the dead person herself or from her family; being a brain dead patient is a transitory situation - medically complex and difficult to maintain - so the procurement process should be done swiftly. This is all the more true for the kidneys once they are extracted from the body since the shorter the cold ischemia (the length of time during which the kidney does not receive oxygen thanks to blood circulation) the higher the odds of success for the graft. As a consequence, kidney membership in Block \#2 does not expand over a few hours: this is fast moving flux, not a stock.

Finally, it is important to bear in mind that the matching institution has some high stake requirement to perform: matching is a business in equality. Matching students with hospitals, pupils with high schools

7 This is all the more critical that there is a significant number of people who died, each year, while on the waiting list, even when there is a medical alternative (dialysis) which works well. For example, data available indicates that the attrition rate for the people waiting for a kidney graft is $1.6 \%$; however, this rate is increasing with the length of time on the waiting list to reach $2 \%$ after 12 months and to peak at $7 \%$ after 36 months (AGENCE DE LA BIOMÉDECINE, 20I4, p. 9). 
or ESRD patients with kidneys has longstanding implications for the individuals on the demand side of those arenas and, accordingly, individuals and their relatives have a strong attachment to the issue of justice in terms of equal access to the matching device and then on the matching outcomes. This makes sense for the individuals standing in Block \#1, because the stakes are high for those excepting a good high school, a good university since many opportunities will follow or disappear according to the match; this is all the more true for the patients since the quality and length of life is significantly superior for those who benefit from a kidney graft. But this makes sense as well for the clearinghouses which duty is officially to offer equality of access to patients; failing on this ground could trigger a social movement among the population and/or a strong institutional reaction from the government ${ }^{8}$. Equality issues explain as well why Roth was personally involved in redesigning the software initially used to match students and hospitals' positions- even if, according to his testimony, the previous software was functioning correctly on this ground (ROTH; PERANSON, 1999, p. 748-749, 758). Students believed that the software was functioning to the advantage of the hospitals and that it was possible to "game the system". Now, this equality issue seems to be settled; however, it should be noted that the last press release of the National Resident Matching Program ends with the two paragraphs stressing that the software was associated to a Nobel Prize in economics and that it takes applicants' preferences as a basis for the matching'. Legitimacy and equity are still at the heart of the functioning of the Clearinghouse ${ }^{10}$.

8 This happened in Spain when in 1986 the performance of kidney transplantation were considered as unsatisfactory by the patients and their family: consequently, a new institution (the Organización nacional de trasplantes) was created a few years latter (1989). The French institution went as well through significant problems when it was clear that one Parisian hospital was offering a large number of kidneys to patients coming from abroad, but the same country. After an official enquiry, made on the demand of the transplant community, a new organization (Etablissementfrançais des greffes) was created in 1994 (STEINER,2010b, p. 136-138).

9 "The NRMP uses a computerized mathematical algorithm to match applicants with programs using the preferences expressed on their ranked lists. Research on the NRMP algorithm was a basis for awarding The SverigesRiksbank Prize in Economic Science in Memory of Alfred Nobel in 2012. The National Resident Matching Program $\left(\mathrm{NRMP}^{\circ}\right)$ is a private, non-profit organization established in 1952 at the request of medical students to provide an orderly and fair mechanism for matching the preferences of applicants for U.S. residency positions with the preferences of residency program directors":http://www.prweb.com/releases/2016/03/prweb I3277506.htm.

10 These issues are as well at the root of a controversy in France on the functioning of the software in the APB matching device for accessing to French universities. The ministry of education released some information that 


\subsection{Matching kidneys and patients: the French Agence de la biomédecine}

Organ transplantation is a form of commerce between human beings - commerce is here understood as a form of social relation, while market commerce is nothing but a specific form of social relation; commerce occurs on arenas whereas market commerce happens on markets. This commerce is a case in point since market relations have been banned since the American bill known as the National Organ transplant Act, passed in 1984. The ban of the market or the promotion of gift giving as the only legal form of commerce does not mean that there are no economic issues in organ transplantation. Gift giving brings about a form of economy of its own, because there are issues over costs - transplant medicine is very costly - and how to finance them both at the national level and at the micro level of individuals and hospitals (STEINER, 2010b, chap. 5). Furthermore, transplantation involves the production of the required resource - human organs - and then its allocation to patient dully selected to fit the rare organs available for the numerous patients queuing on waiting lists. This allocation requires an elaborate matching system and thus, contrary to those economists that equate economy and markets, and explain how beneficial would be the creation of markets for human organs, Roth has explained that economists can contribute to limit the shortage without going against the ban on the market, but with studying transplantation as a matching arena (ROTH, 2007). More precisely, Roth and his colleagues have implemented their economic engineering showing that the Top Trading Cycle approach was able to create nice opportunities of transplantation between non-compatible pairs of donor and recipient (ROTH; SÖNMEZ; ÜNVER, 2004, 2005;ROTH; SAIDMAN, 2006; SÖNMEZ; ÜNVER, 2013). Without entering too much in the details, Roth's idea is the following: the first step is to create a database, ideally at the national level, to register all the non-compatible pairs. Then, a "Kidney Exchange Clearinghouse" will organize exchanges between these pairs of non-compatible patient and donors. Patients choose the most 
suitable kidney among those available on the database; or they opt to be given priority on a waiting list for a good match with kidneys coming from the post mortem procurement process; or, finally, they can choose to wait for the next matching process if they believe there to be currently no good match. It is further supposed that donors and patients have the same preference. On this basis, the mathematics of pure economics has engendered a software searching for cycles (a closed set of patients-donors exchanging their donors) or w-chains (an open set of patients-donors, since the head of the set will receive a kidney from the waiting list and the tail of the chain will give a kidney to the waiting list). When such cycles and $\mathrm{w}$-chains are revealed, transplants occur and the matching process goes on until there are no more cycles or w-chains. Simulations built on the data provided by the United Network for Organ Sharing show that this matching process significantly increases the number of transplantations, diminishes pressure on the waiting list (because the patients who before could not swap donors were among the many people queuing on the waiting list) and improves the position of patients with type $\mathrm{O}$ blood who suffer from a specific asymmetry: type $\mathrm{O}$ donors are universal donors and always compatible with a patient whatever the latter's blood type, but $\mathrm{O}$ patients must receive an organ from an $\mathrm{O}$ donor.

This economic achievement is impressive. Blocks (incompatible pairs), matching technology and Clearinghouse are thus shown at work in the "world out there". However, this is only one face of the history, since, as mentioned above, the social underpinnings of this matching arena must be taken into account. This is all the more necessary that the matching of non-compatible pairs of donors and recipients is effective for a very limited number of transplants, the huge numbers (even in the US) come with post mortem procurement. The question is thus: are matching technology, Clearinghouse and Blocks as well at work when it comes to transplant with post mortem organs?

In order to be more explicit, it is useful to considering with some details the matching arena of organ transplantation as it is working in contemporary France. This offers the possibility to examine how justice concerns and information flows structure the matching process.

The first thing is to flesh out the abstract structure represented in schema II. The Agence de la biomédecine is the Clearinghouse, Block \#1 is composed 
of all the people inscribed on the waiting list (about 15470 persons end of 2014) and Block \#2 represents the flow of post mortem procured kidneys (about 2720 in 2014). This three dimensions system is run for implementing equality of access and efficiency in the allocation of the rare resource that human kidneys are. For achieving this outcome, the Agence de la biomédecine is organized in view of "optimizing" (a concern that is very common within this medical world) the match between the donors and the kidney as soon as they are appearing in the various French hospitals.

The first concern of the Agence de la Biomédecine is to know what is happening on Block \#1. It is important to bear in mind that the entering Block \#1 does not come automatically once the patients is suffering from end stage renal disease: between this medical status and Block membership, the patient must be inscribed on the national waiting list. According to the last report on the management of renal patients, the inscription procedure is highly restrictive, notably for the old patients: "For the cohort [for the period 2009-14] of 57565 new patients under dialysis, the probability to get a first inscription on the waiting list is $19 \%$ in 12 months, $27 \%$ in 36 months and 29\% in 60 months. Among the 15636 new patients less than 60 years old, these probabilities are respectively: 50, 68 and $71 \%$. Among the new patients between 70 to 74 years old, the same probabilities are: 7, 11 and 12\%" (AGENCE DE LA BIOMÉDECINE, 2014b, p. 252). Furthermore, it is not uncommon to disappear from the list, either for cause of death or because the evolution of the disease makes the graft impossible, temporally or definitively. The waiting time on the list is a major indicator for the Agence, together with the attrition rate of patients. The management of the list is monitored under the two main constraints: an efficiency constraint related to the odds of success of a graft for a given patient and the equity constraint that requires an equal access to transplant medicine for the patients.

Opposite to this Block stands Block \#2 that has some highly specific characteristics: first, membership is very limited in time, between some few hours to no more than 48 hours, the usual maximal cold ischemic time before a graft; second, membership here means membership of a human kidney understood as a resource for transplant surgery. Kidneys enter 
Block \#2 as a consequence of the socially construct altruism (HEALY, 2006; STEINER,2010,) that results from the work done by the politics of exhortation designed by the Agence in order to raise the number of people donating their organs after brain death. This membership, or more precisely, this flow is managed very minutely by the people in the Agence in order not to lose a single kidney.

Now, the actual matching requires that the two Blocks were connected accurately. This is done thanks to an Internet platform - CRISTALfunctioning ceaselessly in order to be able to sort out all the patients on the waiting list that can be matched to a kidney as soon as the latter pops up in the data basis. CRISTAL is thus the place for two data basis: the one for all the patients on the national waiting list and the one for kidneys: the existence of the two opposite Blocks is really located in the software. However, this is not enough for producing matches. According to what is known from matching techniques, each side of the matching arena have to give their preferences on the other side. In the present case, there is no such decision neither from the patients, nor the kidneys. Patients' decision is assumed to be in favor of any fitted kidney, but patients are unable to go beyond this general view; and, kidneys do not deciding anything, but have specific characteristics that transplant medicine is able to decipher. The match is entirely under the supervision of the medical system that works under the two constraints of efficiency and equality. In order to answer these two constraints, the French Agence has rationalized his set of criteria through a score attached to the medical status of all the patients on the waiting list: this matching system is thus an algorithmic one on a Walrasian arena.

A score is a magnitude that is attached to a patient on the waiting list; the score changes with the situation of the patient. According to the value of their score, patients are ranked on the list. The score is built upon compromises between conflicting constraints, and the compromise takes the form of a specific valuation (a parameter of a given value) of relevant items (length of time on the waiting list, quality of the HLA match etc.). Jacquelinet stresses the key role played by the quantification at the heart of the score: "The decision rule becomes parametrized, it is possible to run simulation and to evaluate the outcome. The possibility to modify the parameters permits to refine the functioning of the matching process when 
it is working" (AGENCE DE LA BIOMÉDECINE,2015, p. 7). In that case, as in Roth's work, simulations play a key role in the engineering of the score and, this, on the matching arrangement at the core of the work done by the Agence de la biomédecine.

The design of the score is done first to give priority to patients who are facing urgent need of graft and those who are hyper-immunized; beyond these specific cases, the score is based on the length of time on the waiting list and on dialysis, the quality of HLA match between the body of the recipient and the kidney, the difficulty of access to a graft, so that the people who have a rare HLA type were not excluded from the possibility to get a graft, the time necessary to move the kidney to the patient, and the match between the age of the donor and of the recipient. To this complex series of constraints, there is as well a decision to allocate on a regional basis one of the two kidneys, whereas the other is offered on a national basis. In charge of the design of this score, Christian Jacquelinet explains that the score is grounded on many biological and evidence-based medicine results; however, he makes as well clear that some decisions are not medically based, such as the preference given to young patients.

The use of a score is a recent development that aims to answering both to the efficiency and the equality constraints. Efficiency is improved thanks to a connection to a national data basis of patients, that allows to select a recipient among a larger set of patients, increasing the odds to find a perfect HLA match, and a better fit between the age of the donor and recipient. But efficiency requires as well some considerations about the activity of the various medical staffs in the different hospitals that are homologated for transplant surgery, each of them needing a sufficient amount of transplant per year in order to stay fully efficient. Answering the equality of access issue is a bit more complex to achieve since there are many criteria for measuring this equality: gender, age, geographical localization, blood type, HLA type etc. So the Agence de la biomédecine carefully presents a series of tables showing how the implementation of the score that sorts out patients on the waiting list improves the outcome of the matching process on several grounds (JACQUELINET; HOURMANT, 2015, p. 10-22). 


\section{Big data and the "omnes et singulatim" forms of governmentality}

Economics as matching has as well a political dimension that must be considered carefully, particularly when Walrasian algorithmic matching is at stake. Beyond the formation of Blocks, the process thanks to which an individual is accepted or rejected in a Block, and the key issue of equality of treatment once admitted in a Block, the political dimension of economics as matching is about the form of government of individuals that is making its way in contemporary societies.

\section{I Quantification and governmentality}

As it is now well known, Michel Foucault examined the birth of political economy as a form of government, or "conduct of conducts". The institution of a self regulated market of grain in the $18^{\text {th }}$ century France was thus understood as a solution to a political issue, namely, the production of security to a population on a given territory (FOUCAULT, 2004a) -this what he called governmentality. This form of government is driven by "optimization", in the sense that the issue is not about forbidden behaviors that must be tracked, made illegal and then eradicated from the social body (government by law); it is not about controlling undesirable behaviors through a process of continual monitoring of the population, as it is the case in jails (government by control). Optimization means that some unpleasant, dangerous or even forbidden behaviors will occur, but they are considered as the inescapable components of the best possible social order ${ }^{11}$. Banning by law or controlling these behaviors would end up in a worst (or "less best") social order.

The strong connection between markets, utility optimization-led behaviors and political issues was not examined further by Foucault, who just points it out when he dealt with Gary Becker's approach to law enforcement (FOUCAULT, 2004b, p. 274-80). Historically, we may

II In this sense, Foucault is close to Leibniz' view of theodicy, when the present social order is considered as the best possible order, the order that God has established as a mathematician would find a relative extremum of a function thanks to calculus - a mathematical technique that Leibniz has discovered together with Newton in the end of the $17^{\text {th }}$ century. 
find some interesting evidence from economists of the $19^{\text {th }}$ century who assembled these three pieces together, notably the German mathematician economist Hermann Gossen (STEINER, 2011). However, the time was not ripe for the full development of these ideas: the technical devices necessary to monitor the huge amount of data required to implement some real size governmentality were not available. Societies were still acting in what could be called the Quetelet regime of quantification organized around the mean and its human materialization, the so-called average man ("l'hommemoyen"), then, associated with the study of the distribution of individuals around that central value and then inferential statistics.

This regime of quantification is still at work, obviously, but it is not relevant for the form of governmentality that stands at the core of economics as matching since, as mentioned above, relevant data are then highly personal data monitored by powerful software able to find out the optimal use of resource both at the social level and at the individual one, since the issue is to match an individualized resource to a specific individual. What I suggest to call the Pentland regime of quantification ${ }^{12}$ where quantification is about the individual thanks to the technologies that male possible to manage efficiently a huge number of data - ideally all the relevant data ${ }^{13}$ - within a large population in order to get a fine tuned match between individuals and resources: "Big data give us a chance to view society in all its complexity, through the millions of networks of person-to-person exchanges" (PENTLAND, 2013, p. 11). In that case, governmentality bypasses Quetelet's favorite tools (mean, standard deviation etc.) to reach and manage directly individuals and their interactions, even if Pentland is aware that this move is neither straightforward nor easy: "The biggest barrier to building better societal systems using such massive data, however, is not their size or speed, nor even privacy and accountability in sharing. Instead, the biggest challenge is learning how to build social institutions based on the

12 Alex Pentland is a scientist working in the MIT Medialab. He is the author of Social Physics (PENTLAND,20I3), that - probably unknowingly - replicates the subtitle of the book in which Adolphe Quételet ([1835] 199I) made the case of the average as the quantitative knowledge fitted to the government of the modern society (DESROSIÈRES, 1993).

13 In this sense, data accumulation in Walrasian algorithmic matching is close to the " $\mathrm{N}=$ all" claim made by some big data scholars (MAYER-SCHÖNBERGER; CUKIER,20I3, chap. 2). However, arenas studied here do not fit two other claims: messiness versus accuracy in the data and correlation versus causality. 
analysis of billions of individual connections. We need social physics, so that we can move from system based on averages and stereotypes to ones based on the analysis of individual interactions" (PENTLAND, 2013, p. 185).

The matching arrangements studied so far belong to these institutions that Pentlands is thinking about. They are dealing with a large number of information related to significant number of individuals - about 20.000 in the case of the resident match program set up by Alvin Roth, and about 15.000 people on the waiting list for kidney graft in the Agence de la biomédecine. These data basis are made of individual data, about the body, about intimate wishes thanks to which matching devices are producing the best possible social outcome (good job match for an efficient health system, good body match for getting the cost reducing effect of transplant versus dialysis).

\subsection{From obedience to optimality}

This is a coming back to the pastorate, the government whose characteristic is aptly summarized by the "omnes et singulatim" motto. I think useful to link economics as matching to pastorate as a form of government in order to add a political dimension to this approach to the economy.

According to Foucault the pastorate is specific to the Christian religion in the sense that it is a specific view on the relation between god and the human beings, organized around a three principles (FOUCAULT, 2004a, p. 129-132): pastorate is about the government of a population and its movements; it is benevolent in the sense that the pastor provides subsistence or care to each member of the population and, finally, it deals with each individuals and, at the same time, with the whole population hence the motto "omnes et singulatim". Pastorate is neither political, nor rhetorical nor pedagogical; it is a form of governmentality that is to say a political technology built on purpose for producing subjection through obedience (FOUCAULT, 2004a, p. 177, 187). The subject must reveal the truth that lies within himself, as a way to reaching the state of obedience and thus to get salvation.

In his lectures, Foucault explained that the pastorate went into crisis in the $16^{\text {th }}$ century and fade away in the $17^{\text {th }}$ century to be replaced by police and then political economy. This last form of governmentality 
is significantly different from pastorate since it relies on the interested behavior of human beings - there is a strong element of utilitarianism in the Physiocratic doctrine that Foucault took as a point of departure - and because it is grounded on a new form of truth with the idea that there exist social mechanisms that regulates the social understood as a new form of naturalness (FOUCAULT, 2004a, p. 353, 357) that statistics can quantify.

What we have said so far about the engineering of economic matching suggests that this modern form of economic theory is strongly connected to basic characteristics of pastorate, albeit with some significant differences. In the case of the matching system at the core of transplant medicine, the issue is the government of two symmetrical populations linked by the Clearinghouse, and these populations are constantly moving: they are (in the case of the dead donors) flows or they should be (the patients) transformed into fast running flows, instead of people stuck on the waiting list. This matching system is benevolent since it is about providing care to one Block with the help of the resources offered by the opposite one. Finally, the institution at the center of the matching device has to manage whole populations (patients suffering from end stage renal disease and brain dead patients in ICU) through a highly personalized system, precisely through the set of highly personal data that the Clearinghouse requires for optimizing the match between organs and patients. The quality of the Clearinghouse is thus determined by the fate of the whole populations (patients on the one hands, kidneys on the other) that it has to care about individuals and the fate of each individual (the life of each "functional grafted kidney" and the life of each grafted patient). These are the major commonalities between matching arenas and the pastorate.

There are nevertheless two important differences. The first one comes from the fact that the Clearinghouse is as well busy with the production of one population: obtaining kidneys from dead bodies is not an easy task; it demands a steady amount of work to be achieved and, if possible, to be increased. The second difference is probably more substantial with the key importance given to the flows of information. Contrary to the pastorate, matching devices are not designed to produce obedience; they are built upon the idea that people are self interested, opportunistic and strategic 
players trying to beat the matching system. Accordingly, in line with the basic tenets of the economics of information, incentives are built up in such a way that it is better for the individuals to send their true preferences and data if they wish to get their best match. Economy as matching stretches the series of social arrangements that, according to Foucault, are associated to tell the truth: Greek and Roman pedagogy was an arrangement in which revelation of truth was mainly the business of the one in charge to govern the subject; Christian "psychagogy" aimed at bringing the subject to tell the truth (FOUCAULT, 1981, p. 389-391) and thus gave birth to the confession; with centralized matching arrangements, the subject is still induced to tell the truth in order to optimize her chance to get an access to the valuable resource (life saving organ, a position in a good hospital, a good high-school etc.) that is likely to modify substantially her life. This new social relation to truth could be called "optimagogy". Governmentality is then based on expertise (the matching device) and on the nudging of individuals through a series of fine-tuned incentives so that information sent to the matching device is the true one. However, as in the "libertarian paternalism" at the core of the theory of nudges (THALER; SUNSTEIN, 2008), matching arrangements designed by social engineers, specialists in optimizing theories, leave open the possibility to act otherwise; in other words, these arrangements do not produce obedience or confession but the search of the optimal situation for the subject. Finding one's way towards optimality is thus the characteristic of this form of information-led governmentality, both for the Clearinghouse at the center of the matching device and the subject.

\section{Conclusion}

This communication is a first attempt at delineating the changes that are bought by algorithmic matching in our present society when it comes to fulfill the usual issue related to the distribution of useful, scarce resources that are different in terms of quality; most of them are thus singularities. In this sense, matching belongs to economic life, whether the exchanges are occurring on markets or on non-market arenas. In any cases, equilibrium and optimality are defined in a specific way, generally without any tag price or the use of money, but directly through preferences of the two sets of actors who are on the arena. The first conclusion is thus that matching 
structures blur the distinction between markets and non-market arenas, between compulsory and optional matching and between self-interested behavior and altruism or gift giving: the same economic apparatus can be implemented in any of these settings.

Beyond a brief presentation of the properties of the algorithms, this communication has stressed the matching structure made of two Blocks and a Clearinghouse as the social constituents of matching arena. The social dimension is dominated by concerns about freedom and justice: freedom to access the matching arena and social justice when it comes to decide who will be admitted on the matching arena, then social justice about the outcome of the matching software. This means that access to matching arenas is becoming an issue for the good functioning of our present society, as access to markets was and still is an important issue. Furthermore, freedom and justice are complicated to implement since actors in the Blocks are usually very different (individuals and organization) and the way they confront the choices offered on these matching arenas for singular and key resources is significantly different as well. The choice is most engaging for the individuals but it is once in a life choice; whereas, it is a continuous process for the people in charge of the organizations who have the possibility to benefit from a learning by doing. The rampant asymmetry on these arenas that cannot be controlled solely by incentives to send the good information to the Clearinghouse highlights the need of social justice.

Finally, the last conclusion is about the political dimension of matching arenas. Following Foucault's approach of pastorate understood as a form of governmentality, the final conclusion of this communication is to stress that matching arenas are new devices for governing the conduct. The crucial point is not so much the quantitative nature of this governmentality because this is the case at least from since the end of the $19^{\text {th }}$ century; the new phenomena is the close association of matching arenas and a highly personalized government of each individuals and of the whole population. In this sense, economics as matching and its social underpinnings are giving flesh in our present society to the old "Omnes et singulatim" religious motto according to which the government has to take care of each individual in particular and the whole population, be it with the relief provided by libertarian paternalism. 


\section{References}

ABDULKADIROĞLU, A, 2013. School Choice. In:VULKAN, N.; ROTH, A. E.; NEEMAN, Z (ed.). Handbook of Market Design. Oxford: Oxford University Press, 2013. p. 138-169.

AGENCE DE LA BIOMÉDECINE,2013. Procédures d'application des règles de répartition et d'attribution des greffons prélevés sur personne décédée. Saint-Denis: Agence de la Biomédecine, 2013.

AGENCE DE LA BIOMÉDECINE. Le rapport médical et scientifique du prélèvement et de la greffe en France - rein. Saint-Denis: Agence de la Biomédecine, $2014 a$.

AGENCE DE LA BIOMÉDECINE. Rapport Annuel: Réseau, Epidémiologie, Information, Néphrologie. Saint-Denis : Agence de la Biomédecine, 2014b.

AGENCE DE LA BIOMÉDECINE. Du don à la greffe. L'attribution des greffons. Les journées de l'Agence de la Biomédecine 2015. Saint-Denis: Agence de la biomédecine, 2015.

BECKER, G. S. [1973]. A Theory of Marriage.In: BECKER, G. S. The Economic Approach to Human Behavior. Chicago: University of Chicago Press: 1978. p. 205-250.

CISION PRW.Results Of 2016 NRMP Main Residency Match Largest On Record As Match Continues To Grow.2016. Available at: http://www.prweb.com/releases/2016/03/ prweb13277506.htm Accessed on: aug. 11th 2019.

COLEMAN, J. S.Introducing Social Structure into Economic Analysis.American Economic Review, v. 74, n. 2, p. 84-88, 1984.

COLEMAN, J. S.1990. Foundations of Social Theory, Harvard: The Belknap Press, 1990.

DESROSIÈRES, A. La politique des grands nombres. Une histoire de la raison statistique.Paris: La Découverte, 1993.

DUPREZ, J.-M.; BARBUT, M.Apprécier l'homogénéité dans la formation des paires. Similitudes et liens sociaux dans le choix du partenaire en aïkido.Revue française de sociologie, v. 48, n. 2 , p. 333-367, 2007.

EVANS, D. S.; SCHMALENSEE, R.Matchmakers. The New economics of Multisided Platforms. Boston: Harvard Business Review Press, 2006.

FAUST, K.;WASSERMAN, S. Social Network Analysis. Methods and Application. Cambridge: Cambridge University Press, 1994.

FOUCAULT, M. Omnes et singulatim: vers une critique de la raison politique. In:FOUCAULT, M. Dits et écrits. Paris: Gallimard, 1981. p. 953-980.

FOUCAULT, M. [1981-1982]. L'herméneutique du sujet. Cours au Collège de France. Paris: Gallimard-Seuil, 2001.

FOUCAULT, M. Sécurité, territoire, population: Cours au Collège de France, 1977-1978. Paris: Gallimard-Seuil, 2004a. 
FOUCAULT, M. Naissance de la biopolitique: Cours au Collège de France, 1978-1979. Paris: Gallimard-Seuil, 2004b.

FRANÇOISE, F.; GUILLAUME, H.; IEHLÉ, V. Appariement: des modèles de Lloyd Shapley à la conception des marchés d'Alvin Roth. Revue d'économie politique, v. 123, n. 5, p. 663-696, 2013.

GALE, D.; SHAPLEY, L.College Admissions and the Stability of Marriage.The American Mathematical Monthly, v. 69, n. 1, p. 9-15, 1962.

Granovetter, M. Getting A Job: A Study of Contacts and Careers. Harvard University Press, 1974, $179 \mathrm{pp}$.

HAUTE AUTORITÉ DE LA SANTÉ. Transplantation rénale. Accès à la liste d'attente nationale. Méthode Recommandations pour la pratique clinique. Saint-Denis: Haute Autorité de la Santé, 2015.

HAYEK, F.Law, Legislation and Liberty:The Mirage of Social Justice.London: Routledge and Kegan Paul, 1976.

HEALY, K.Last Best Gift.Altruism and the Market for Human Blood and Organ. Chicago: Chicago university Press, 2006.

HILLER, V.; TERCIEUX, O.Choix d'école en France. Une évaluation de la procédure Affelnet. Revue économique, v. 65, n. 3, p. 619-656, 2014.

JACQUELINET, C.; AUDRY, B.; GOLBREICH, C.; ANTOINE, C.; REBIBOU, J.-M.; CLAQUIN, J.; LOTY, B.Changing Kidney Allocation Policy in France: the Value of Simulation. AMIA Symposium Proceeedings, p. 374-378, 2006.

JACQUELINET, C.?.Organ Sharing and Allocation Criteria. In:RICARD, R. (ed.). Transplant Coordination Manual. Barcelona: Donation and Transplant Institute, 2007. p. 28-42.

JACQUELINET, C.; AUDRY, B.; PESSIONE, F.; CORINNE, A.; LOTY, B.; CALMUS, Y. Règles d'attribution des greffons hépatiques.La presse médicale,v. 37, n. 12, p. 1782-1786, 2008.

JACQUELINET, C.; HOURMANT, M.Le nouveau score rein. Saint-Denis: Agence de la Biomédecine, 2015.

KARPIK, L. Valuing the Unique. The Economy of singularities. English translation. Princeton: Princeton University Press, 2010.

LORRAIN, F.; WHITE, H. C.Structural equivalence of individuals in social networks.Journal of Mathematical Sociology, v. 1, p. 49-80, 1971.

MARSHALL, A. [1920]. Principles of Economics. Variorum edition. London: MacMillan, 1961.

MAYER-SCHÖNBERGER, V.; CUKIER, K.Big Data. A Revolution That Will Transform How We Live. Work and Think. London: John Murray, 2013. 
MOGELL, S.; ROTH, A. E.Sorority Rush as a Two-Sided Matching Mechanism.American Economic Review, v. 81, n. 3, p. 441-464, 1991.

MORTENSEN, D. T.Matching: Finding a Partner for Life or Otherwise. American Journal of Sociology.Supplement, p. 215-240, 1988.

PARKER, G. G.; VAN ALSTYNE, M. W.; CHOUdARY, S. P. Platform Revolution. How Networked Markets Are Transforming the Economy and How to Make Them Work for You. New York: Norton, 2016.

PENTLAND, A.Social Physics: How Good Ideas Spread. Lessons from a New Science. New York: Penguin Books, 2013.

QUETELET, A. [1835].Sur l'homme et le développement de ses facultés ou essai de physique sociale. Paris: Fayard, 1991.

ROTH, A. E. The evolution of the labor market for medical interns and residents: A case study in game theory.Journal of Political Economy, v. 92, n. 2, p. 991-1016, 1984.

ROTH, A. E. A natural experiment in the organization of entry-level labor markets: regional markets for new physicians and surgeons in the United Kingdom.American Economic Review, v. 81, n. 3 , p. $415-440,1991$.

ROTH, A. E. The economist as engineer: game theory, experimental economics and computation as tool for designing economics.Econometrica, v. 70, n. 4, p. 1341-1378, 2002.

ROTH, A. E.The origins, history, and design of the resident match.Journal of the American Medical Association, v. 289, n. 7, p. 909-912, 2003.

ROTH, A. E. Repugnance as a constraint on markets.Journal of Economic Perspectives, v. 21, n. 3, p. 37-58, 2007.

ROTH, A. E. Deferred acceptance algorithms: history, practice and open questions.International Journal of Game Theory, v. 36, p. 537-569, 2008.

ROTH, A. E. What Have We Learned from Market Design?.In:VULKAN, N.; ROTH, A. E.; NEEMAN, Z (ed.). Handbook of Market Design. Oxford: Oxford university Press, 2013. p. 1-50.

ROTH, A. E.; PERANSON, E. The Redesigning of the Matching Market for American Physicians. Some Engineering Aspects of Economic Design”, American Economic Review, v. 89, n. 4, p. 748-780, 1999.

ROTH, A. E.; SAIDMAN, S.Increasing the Opportunity of Live Kidney Donation by Matching for Two-and Three-Way Exchanges.Transplantation, v. 81, n. 5, p. 773-782, 2006.

ROTH, A. E.; SÖNMEZ, T.; ÜNVER, U. M.Kidney Exchange.Quarterly Journal of Economics, v. 119, n. 2, p. 457-488, 2004.

ROTH, A. E.; SÖNMEZ, T.; ÜNVER, U. M.A Kidney Exchange Clearinghouse in New England. AmericanEconomic Review, v. 95, n. 2, p. 376-380, 2005. 
ROTH, A. E.; ROTH; VANDE VATE, J. H.Random Path to Stability in Two-Sided Matching. Econometrica, v. 58, n. 6, p. 1475-1480, 1990.

RYSMAN, M.The Economics of Two-Sided Markets.Journal of Economic Perspectives, v. 23, n. 3, p. 125-143, 2009.

SMITH, A. [1776]. An Inquiry into the Nature and the Cause of the Wealth of Nations. Indianapolis: Liberty Classics, 1981.

SÖNMEZ, T.; ÜNVER, U. M.Market Design for Kidney exchange.In: VULKAN, NIR, ROTH, A. E.; NEEMAN, Z. (ed.). Handbook of Market Design. Oxford: Oxford University Press, 2013. p. 93-137.

STEINER, P. Foucault, Weber and the history of the economic subject. European Journal of the History of Economic Thought,v. 15, n. 3, p. 503-527, 2008.

STEINER, P. Market or Gift-Giving. Economists and the performation of organ commerce. Journal of Cultural Economy, v. 3, n. 2, p. 243-249, 2010a.

STEINER, P. La transplantation d'organes: un commerce nouveau entre les êtres humains. Paris; Gallimard, 2019b.

STEINER, P. The creator, human conduct and the maximisation of utility in Gossen's economic theory”, European Journal of the History of Economic Thought, v. 18, n. 3, p. 353-379, 2011.

STEINER, P.Altruísmo, dons e troca simbólica. São Carlos: Editora UNESP, 2016.

STOVEL, K.; FOUNTAIN, C. Matching. In:HEDSTRÖM, P.; BEARMAN, P. (ed.). The Oxford Handbook of Analytical Sociology. Oxford: Oxford university Press, 2009. p. 365-390.

TERVEEN, L.; MCDONNALD, D. W.Social Matching: A Framework and Research Agenda. ACM Transactions on Computer-Human Interaction, v. 12, n. 3, p. 401-434, 2005.

THALER, R. H.; SUNSTEIN, C. R. Nudge: Improving Decisions About Health, Wealth and Happiness, Yale, Yale university Press, 2008.

TIROLE, J.Economie du bien commun. Paris: Presses universitaires de France, 2016.

TURGOT, A.R. J.Réflexions sur la formation et la distribution des richesses.In:TURGOT, A. R. J. [1766]. Euvres de Turgot et documents le concernant. Paris: Alcan, 1914. vol. II. p. 1-29.

WALRAS, L. [1900]. Eléments d'économie politique pure. Euvres complètes de Léon Walras, vol. VIII. Paris:Economica, 1988.

WHITE, H. C. Identity and Control. A Structural Theory of Social Action. Princeton: Princeton university Press, 1992. 


\section{Economia como Matching ${ }^{14}$}

\section{Resumo}

Recentemente, uma nova definição da economia apareceu onde o conceito de match ocupa um lugar central. Matching significa que existem algumas questões específicas relacionadas à associação efetiva de um determinado recurso a uma determinada pessoa. O match pode, portanto, parecer uma extensão da questão tradicional relacionada à distribuição da riqueza; contra essa aparência, o presente artigo enfatiza que algo mais está em jogo quando se trata de entender como o match é realmente implementado.

A primeira parte do artigo é dedicada a explicar o que se entende por match no estado atual da economia, com ênfase especial nas obras de Alvin Roth. A segunda parte é sobre os fundamentos sociológicos da abordagem através do match em relação às questões econômicas, mostrando como ela é diferente do mercado. Finalmente, a terceira parte conecta a economia como match à compreensão de pastorado de Michel Foucault, focalizando as mudanças trazidas pela enorme quantidade de dados e a tecnologia necessária para implementar uma nova forma de governamentalidade, aquela em que, na esteira do antigo preceito religioso, requer que o líder governe a população como um todo e cada indivíduo em particular ("omnes et singulatim" nos termos de Foucault).

Palavras-chave: Matching; Algoritmo; Sociologia Econômica.

I4 NT. Alguns autores tem traduzido essa expressão por Emparelhamento e Correspondência, mas optamos por manter no inglês. 